\title{
Systemic Treatment for Gastrointestinal Stromal Tumor-A State of Art
}

\author{
Xiaolan Feng, MD, PhD, FRCPC ${ }^{1}$ and Don Morris, MD, PhD, FRCPC ${ }^{2}$ \\ 1. Medical Oncology Fellow; 2. Associate Professor, Tom Baker Cancer Center, Cancer Control, Alberta Health Services, Calgary, Alberta, Canada
}

\begin{abstract}
The availability of the tyrosine kinase inhibitor (TKI) small molecule imatinib has revolutionized the systemic treatment for gastrointestinal stromal tumor (GIST), historically one of the most chemoresistant solid malignancies. Prior to imatinib availability approximately 14 years ago, surgery was the only effective treatment modality. Imatinib is now accepted as the first-line systemic treatment for advanced GIST and subsequently has become the standard systemic treatment for GIST in the neoadjuvant and adjuvant settings. Sunitinib and regorafenib have been approved for second- and third-line treatments, respectively, for patients with advanced GIST progressing on imatinib. The dramatic and continuing efficacy of TKIs targeting oncogenic driver pathways such as KIT, platelet-derived growth factor receptor alpha (PDGFR $\alpha$ ), and vascular epithelial growth factor receptors (VEGFS), in advanced GIST supports the utility of targeted therapy in oncogene addicted solid malignancies. Molecular mutational diagnostics has further defined subpopulations of responders. Although significant gains have been made in the treatment of GIST patients, future research is still warranted to help further improve clinical outcomes of patients with GIST.
\end{abstract}

\section{Keywords}

Gastrointestinal stromal tumor (GIST), KIT, platelet-derived growth factor receptor alpha (PDGFR $\alpha$ ), complete response (CR), partial response (PR), stable disease (SD), disease-free survival (DFS), overall survival (OS), neoadjuvant, adjuvant, metastatic/advanced

Disclosure: Xiaolan Feng, MD, PhD, FRCPC and Don Morris, MD, PhD, FRCPC, have no conflicts of interest to declare. No funding was received in the publication of this article. Received: July 8, 2014 Accepted: September 18, 2014 Citation: Oncology \& Hematology Review, 2014;10(2):110-22 DOI: 10.17925/OHR.2014.10.2.110 Correspondence: Xiaolan Feng, MD, PhD, FRCPC, Tom Baker Cancer Center, Cancer Control, Alberta Health Services, 1331 29th ST NW, T2N 4N1, Canada. E: fxiaolan@ucalgary.ca

Gastrointestinal stromal tumors (GISTS) are the most common mesenchymal tumor of the gastrointestinal tract. They are thought to be derived from the interstitial cells of Cajal, the so-called pacemaker cells that regulate gastrointestinal peristaltic function. The annual incidence of GIST is approximately 10-15 per million population with some regional variation, making them the most common subtype of sarcoma. More than a decade ago, systemic chemotherapy for GIST was very disappointing with response rates typically reported of 5-7\%. Surgery was and perhaps is still the only curative modality. The report of the KIT oncogene as the major driver mutation of GIST in $1998^{2}$ coupled with the first case report ${ }^{3}$ of a chemotherapy refractory GIST patient (with liver and peritoneal metastasis) that demonstrated a dramatic radiographic response to imatinib demonstrated one of the first successful examples of utilizing targeted therapy for oncogene addicted solid malignancies. In this review, we will summarize and highlight the historical and recent advancements in the systemic treatment of GIST in the metastatic, adjuvant, and neoadjuvant settings.

\section{Inoperable/Metastatic Therapy}

\section{First Line-Imatinib}

There are few controversies in choosing initial systemic therapy in the management of unresectable advanced or metastatic GIST based on several phase III clinical trials (see Table 1). Level 1 evidence supports the use of imatinib as first-line treatment for advanced/metastatic GIST based on its high clinical benefit rate of $80 \%$, median progression-free survival (mPFS) approaching 24 months, and a median overall survival (mOS) of nearly 5 years based on extended follow-up of the initial pivotal B2222 phase II trial $\left.\right|^{4,5}$ and two large phase III (EORTC62005 ${ }^{6}$ and SWOGS00337) trials.

The European (EORTC62005) ${ }^{6}$ and North American trial (SWOGS0033) compared imatinib $400 \mathrm{mg} /$ day versus $800 \mathrm{mg} /$ day as the initial therapy allowing for crossover at progression in nearly 1,700 patients GIST patients combined. These trials have established imatinib $400 \mathrm{mg} /$ day as the initial treating dose for most patients, as there was no difference between the low- and high-dose arms in terms of response rate and PFS rate. ${ }^{6,7}$ Post hoc tumor mutation analysis in both trials demonstrated that patients with KIT exon 9 mutant tumors had a significantly shorter PFS than patients harboring a KIT exon 11 mutation..$^{6,7}$ In addition, patients with KIT exon 9 mutant tumors appear to have a longer PFS if treated at $800 \mathrm{mg} /$ day versus 400 mg/day; however, this did not translate into an OS benefit likely due to the fact that tumor control can be restored in many of these patients by using $800 \mathrm{mg}$ upon disease progression or switching to a second-line therapy. ${ }^{6,7}$ Thus it is unclear that exon 9 mutant GIST patients should be treated at a starting dose of $800 \mathrm{mg}$ /day versus a standard dose of $400 \mathrm{mg} /$ day followed by escalation to $800 \mathrm{mg} /$ day upon progression. We do know, however, from toxicity data that tolerance is improved with escalation from $400 \mathrm{mg}$ to $800 \mathrm{mg}$ over several weeks. Therefore, our 
Table 1: Pivotal Clinical Trials of Systemic Treatment in Unresectable Advanced and Metastatic GIST

\begin{tabular}{|c|c|c|c|c|c|c|c|}
\hline Study & Treatment $P$ & Pt No. & Intervention & Main Inclusion Criteria & TTP/PFS & OS & Safety \\
\hline $\begin{array}{l}\text { Demetri et al. }{ }^{4} \\
\text { Blanke et al. } \\
\text { B2222 } \\
\text { Randomized } \\
\text { phase II }\end{array}$ & $\begin{array}{l}\text { First line: } \\
\text { imatinib }\end{array}$ & $\begin{array}{l}26 \text { on } \\
\text { extension } \\
\text { study }\end{array}$ & $\begin{array}{l}\text { Imatinib } 400 \text { mg/d vs } \\
600 \text { mg/d for } 3 \text { yrs; } \\
\text { Extension as long as } \\
\text { clinical benefit } \\
\text { (>9 yrs ongoing) }\end{array}$ & $\begin{array}{l}\text { Metastatic and or } \\
\text { unresectable advanced } \\
\text { GIST with no prior imatinib }\end{array}$ & $\begin{array}{l}20 \text { vs } 26 \text { mos } \\
\text { ( } p=0.37) ; \text { mTTP } \\
\text { of } 24 \text { mos } \\
\text { TTP: } 14 \% \text { at } \\
9 \text { yrs }\end{array}$ & $\begin{array}{l}\text { mOS: } 57 \text { mos; } \\
\text { no difference } \\
\text { between two arms } \\
\text { Os: } 35 \% \text { at } 9 \text { yrs }\end{array}$ & $\begin{array}{l}\text { Imatinib is well tolerated over } \\
\text { long-term administration, no } \\
\text { new AEs with longer F/U, no } \\
\text { patients withdrew study } \\
\text { because of AES }\end{array}$ \\
\hline $\begin{array}{l}\text { Verweij et al. }{ }^{6} \\
\text { EORTC62005 } \\
\text { phase III }\end{array}$ & $\begin{array}{l}\text { First line: } \\
\text { imatinib }\end{array}$ & 946 & $\begin{array}{l}\text { Imatinib } 400 \mathrm{mg} / \mathrm{d} \text { vs } \\
800 \mathrm{mg} / \mathrm{d} \text { until } \\
\text { progression, the } \\
\text { crossover allowed }\end{array}$ & $\begin{array}{l}\text { Metastatic and or } \\
\text { unresectable advanced } \\
\text { GIST with no prior imatinib }\end{array}$ & $\begin{array}{l}56 \% \text { vs } 50 \% \\
(\mathrm{HR}=0.82 ; \mathrm{p}=0.026) \\
\text { at } \mathrm{mF} / \mathrm{U} \text { of } 760 \mathrm{ds}\end{array}$ & $\begin{array}{l}85 \% \text { vs } 86 \% \text { at } 1 \text { yr; } \\
69 \% \text { vs } 74 \% \text { at } 2 \text { yrs; } \\
\text { no difference between } \\
\text { two arms }\end{array}$ & $\begin{array}{l}\text { Patients on } 800 \mathrm{mg} / \mathrm{d} \text { arm } \\
\text { required more dose reductions } \\
\text { ( } 60 \% \text { vs } 16 \% \text { ) and more } \\
\text { treatment interruptions ( } 64 \% \\
\text { vs } 40 \% \text { ) }\end{array}$ \\
\hline $\begin{array}{l}\text { Blanke et al. } .^{7.11} \\
\text { Demetri et al. }{ }^{12} \\
\text { swoG0033 } \\
\text { phase III }\end{array}$ & $\begin{array}{l}\text { First line: } \\
\text { imatinib }\end{array}$ & 746 & $\begin{array}{l}\text { Imatinib } 400 \mathrm{mg} / \mathrm{d} \\
\text { vs } 800 \mathrm{mg} / \mathrm{d} \text { until } \\
\text { progression, the } \\
\text { crossover allowed }\end{array}$ & $\begin{array}{l}\text { Metastatic and or } \\
\text { unresectable advanced } \\
\text { GIST with no prior imatinib }\end{array}$ & $\begin{array}{l}18 \text { vs } 20 \text { mos at } \\
m F / U \text { of } 4.5 \text { yrs } \\
(p=0.13)\end{array}$ & $\begin{array}{l}55 \text { vs } 51 \text { mos at } \mathrm{mF} / \mathrm{U} \\
\text { of } 4.5 \mathrm{yrs} ;(\mathrm{HR}=0.98 ; \\
\mathrm{p}=0.98) ; \\
\text { Long-term survival } \\
\text { data: } 31 \% \text { at } 8 \mathrm{yrs} ; \\
26 \% \text { at } 9 \mathrm{yrs}, 22 \% \\
\text { at } 10 \mathrm{yrs}\end{array}$ & $\begin{array}{l}\text { Patients on } 800 \mathrm{mg} / \mathrm{d} \\
\text { experience more grade } \geq 3 \\
\text { AEs than those on } 400 \mathrm{mg} / \mathrm{d} \\
\text { ( } 63 \% \text { vs } 43 \%)\end{array}$ \\
\hline $\begin{array}{l}\text { Le Cesne et al. }{ }^{9} \\
\text { Patrikidou et al. }{ }^{.9} \\
\text { BFR14 } \\
\text { phase III }\end{array}$ & $\begin{array}{l}\text { First line: } \\
\text { imatinib } \\
\text { (continuous } \\
\text { vs intermittent) }\end{array}$ & 434 & $\begin{array}{l}\text { Continuous imatinib } \\
\text { ( } 400 \mathrm{mg} / \mathrm{d}) \text { vs } \\
\text { interrupted at } \\
1-, 3-\text {, and } 5 \text { yrs }\end{array}$ & $\begin{array}{l}\text { Metastatic and or } \\
\text { unresectable advanced } \\
\text { GIST with no prior imatinib } \\
\text { who achieved CR/PR/SD } \\
\text { at 1-, 3-, and } 5 \text { yrs of } \\
\text { imatinib treatment }\end{array}$ & $\begin{array}{l}7 \text { vs } 29 \text { mos at } 1 \mathrm{yr} \\
\text { at mF/ } \mathrm{U} \text { of } 74 \text { mos; } \\
9 \text { mos vs not } \\
\text { reached at } 3 \mathrm{yrs} \\
\text { at mF/ } \mathrm{U} \text { of } 47 \text { mos; } \\
13 \text { mos vs not } \\
\text { reached at } 5 \mathrm{yrs} \\
\text { at } \mathrm{mF} / \mathrm{U} \text { of } 18 \mathrm{mos}\end{array}$ & No OS difference & $\begin{array}{l}\text { Grade } \geq 3 \text { AEs similar in } \\
\text { both groups }\end{array}$ \\
\hline $\begin{array}{l}\text { Demetri et al. }{ }^{20} \\
\text { phase III }\end{array}$ & $\begin{array}{l}\text { Second line: } 3 \\
\text { sunitinib }\end{array}$ & 312 & $\begin{array}{l}\text { Sunitinib ( } 50 \mathrm{mg} / \mathrm{d} 4 \\
\text { wks on and } 2 \text { wks off) } \\
\text { vs placebo until } \\
\text { progression, the } \\
\text { crossover allowed }\end{array}$ & $\begin{array}{l}\text { Metastatic or unresectable } \\
\text { advanced GIST failure of } \\
\text { previous imatinib therapy }\end{array}$ & $\begin{array}{l}\text { TTP: } 27.3 \text { vs } 6.4 \\
\text { wkS (HR=0.33; } \\
p<0.0001)\end{array}$ & $\begin{array}{l}\text { mos not reached in } \\
\text { sunitinib group } \\
\text { (HR 0.49, } \mathrm{p}=0.007)\end{array}$ & $\begin{array}{l}\text { The most common grade 1-2 } \\
\text { fatigue, diarrhea, skin } \\
\text { discoloration, and nausea } \\
\text { Minimal grade 3-4 AEs }\end{array}$ \\
\hline $\begin{array}{l}\text { Demetri et al. }{ }^{24} \\
\text { GRID } \\
\text { phase III }\end{array}$ & $\begin{array}{l}\geq \text { Third line: } \\
\text { regrafenib }\end{array}$ & 199 & $\begin{array}{l}\text { Regorafenib } \\
\text { (160 mg/d) vs placebo } \\
\text { until progression, } \\
\text { the crossover allowed }\end{array}$ & $\begin{array}{l}\text { Metastatic or unresectable } \\
\text { advanced GIST had } \\
\text { progressed on at least } \\
\text { imatinib and sunitinib }\end{array}$ & $\begin{array}{l}4.8 \text { vs } 0.9 \text { mos } \\
(H R=0.27 \\
p<0.0001)\end{array}$ & $\begin{array}{l}22 \% \text { vs } 26 \% \text { events } \\
(\text { HR } 0.77 ; p=0.199)\end{array}$ & $\begin{array}{l}\text { The most common } \geq \text { grade } 3 \\
\text { AEs were hypertension, } \\
\text { hand-foot skin reaction, and } \\
\text { diarrhea }\end{array}$ \\
\hline $\begin{array}{l}\text { Kang et al. }{ }^{25} \\
\text { RIGHT } \\
\text { phase III }\end{array}$ & $\begin{array}{l}\text { 2Third line: } 8 \\
\text { rechallenge } \\
\text { of imatinib }\end{array}$ & 81 & $\begin{array}{l}\text { Imatinib ( } 400 \mathrm{mg} / \mathrm{d} \text { ) } \\
\text { vs placebo until } \\
\text { progression, the } \\
\text { crossover allowed }\end{array}$ & $\begin{array}{l}\text { Metastatic or unresectable } \\
\text { advanced GIST progressed } \\
\text { on at least imatinib and } \\
\text { sunitinib but had previously } \\
\text { benefited from first-line } \\
\text { imatinib (initial response } \\
\text { or SD for } \geq 6 \text { mos) }\end{array}$ & $\begin{array}{l}1.8 \text { vs } 0.9 \text { mos } \\
\text { (HR 0.46; } \\
p=0.005)\end{array}$ & $\begin{array}{l}8.2 \text { vs } 7.5 \text { mos } \\
\text { (HR 1.00; } p=0.92)\end{array}$ & $\begin{array}{l}\text { The most common } \geq \text { grade } 3 \\
\text { AEs were anemia, fatigue, } \\
\text { and hyperbilirubinemia }\end{array}$ \\
\hline
\end{tabular}

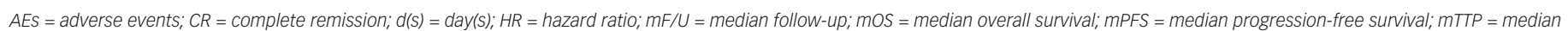
time to progression; $m o(s)=$ month(s); no. = number; $P R=$ partial response; $p t=$ patient; $S D=$ stable disease; $y r(S)=y e a r(s)$.

institution prefers to initiate $400 \mathrm{mg} /$ day in all fit patients and escalate to $800 \mathrm{mg}$ /day upon disease progression regardless of tumor mutation status. This calls into question the routine tumor mutation testing in metastatic setting for the majority of cases. Whether one should image a patient with an exon 9 mutation more frequently in this case is uncertain. It should also be noted that only about one-third of patients will respond to this dose escalation upon disease progression and the median time of benefit of disease control with imatinib dose escalation is relatively short, estimated at 11.6 weeks. $^{8}$

Imatinib should be continued indefinitely in nonprogressing tolerant patients with metastatic disease. The importance of continuous imatinib therapy in advanced GIST patients was demonstrated from the long-term follow-up results of the phase II B2222 study ${ }^{5}$ and updated results of the BFR14 trial, 9,10 (a randomized, open label, phase III study assessed the impact of interrupting therapy after 1 year, 3 years, or 5 years of imatinib [400 mg/day] treatment in patients with advanced GIST). Both of these trials demonstrated that interruption of imatinib therapy results in rapid disease progression even in patients who had initially achieved complete response (CR), whereas long-term continuous imatinib treatment is associated with reduced risk for disease relapse and progression. It is notable that onethird of patients were on continuous imatinib for more than 9 years on the extended B2222 study, 4,5 similar to the long-term survival data reported in SWOGS0033, which showed a $26 \%$ OS at 9 years and $22 \%$ OS at 10 years. ${ }^{11,12}$ 
Moreover, both of these studies confirmed safety of long-term duration of imatinib therapy with no reported new toxicity or adverse events.

In any long-term therapy, the matter of medication adherence is of potential concern. The rate of noncompliance to imatinib has been reported variably between $30-70 \%$ using various methodologies to measure drug adherence. ${ }^{13-15}$ We have found that in our center that around half of advanced GIST patients will exhibited some level of noncompliance to tyrosine kinase inhibitors (TKIS). ${ }^{16}$ Multivariate analysis suggests that one of the major reasons for nonadherence is living alone social status $(p=0.01)$, although longer duration of therapy, female gender, and older age also trended toward negatively impacting TKIs adherence, ${ }^{16}$ which is consistent with the results of other studies. ${ }^{17}$

Inadequate imatinib plasma blood levels have also been associated with disease progression and poor clinical outcome in patients with GIST. A retrospective pharmacokinetic analysis of the B2222 study demonstrated patients in the lowest quartile of imatinib trough levels $(<1,100 \mathrm{ng} / \mathrm{ml})$ had a shorter time to progression than patients in all other quartiles (11.3 versus 30 months; $p=0.029) .{ }^{18}$ In addition, a recent retrospective study showed that the minimal imatinib plasma level of 20 long-term responders who had been on imatinib for more than 5 years was 789 ng/ml, suggesting that perhaps even a lower imatinib plasma level maybe effective. ${ }^{19}$ We also confirmed that the lower cutoff in our imatinib adherence study may be a more appropriate target. ${ }^{16}$ It is not yet clear however that imatinib plasma levels should be used to help guide clinical management of GIST patients on imatinib as there are many factors affecting the level such as medication adherence, duration of medication use, previous gastrectomy, concomitant medications, and individual pharmacokinetics.

\section{Second Line-Sunitinib}

Acquired resistance to imatinib occurs in the majority of patients with metastatic GIST who have initially responded to imatinib at standard dose of $400 \mathrm{mg} /$ day and/or escalated dose $800 \mathrm{mg} /$ day. Tumor progression usually occurs at a median of 18-24 months of continuous imatinib use. When this occurs, utilization of a different oral TKI may rescue disease control. Sunitinib (Sutent), an oral multitargeted receptor TKI, is the most well-studied second-line treatment after failure of imatinib treatment. It not only binds and inhibits the KIT and PDGFR $\alpha$ receptors, but also inhibits other receptors such as vascular epithelial growth factor receptors (VEGFRS). The efficacy of sunitinib has been demonstrated in a pivotal phase III trial, ${ }^{20}$ which assessed 312 patients who were resistant to or intolerant of imatinib. The time to tumor progression, which was the primary endpoint of the study, was significantly prolonged in patients receiving sunitinib $(50 \mathrm{mg} /$ day for 4 weeks every 6 weeks) compared with placebo (27.3 versus 6.4 weeks; hazard ratio $[H R]=0.33 ; p<0.0001)$. The study was stopped at the planned interim analysis as the primary endpoint had been met. This study also showed an improved OS in patients despite the availability of the option to crossover upon disease progression if on placebo (HR 0.49, $95 \%$ confidence interval [Cl] 0.29-0.83; $p=0.007$ ). The toxicity of sunitinib such as fatigue, hand-foot syndrome, diarrhea, and hypertension were mild to moderate in intensity and easily managed by dose reduction, dose interruption, and supportive treatments. This trial has led to the approval of sunitinib as the standard second-line treatment after imatinib (either progression on or intolerance to imatinib) in metastatic GIST. The small phase II studies ${ }^{21,22}$ showed that the efficacy and side effects of continuous dosing of $37.5 \mathrm{mg}$ / day were similar to standard intermittent dosing of $50 \mathrm{mg} /$ day 4 weeks on and 2 weeks off. The escalation of imatinib to $800 \mathrm{mg} /$ day or an immediate switch to sunitinib for patients who progress on standard dose of imatinib at $400 \mathrm{mg} /$ day remains controversial. There was one clinical trial (ClinicalTrials.gov; NCT00372567) designed to answer this question, but it was unfortunately terminated due to poor recruitment. Sunitinib appears to be more sensitive to GIST tumors harboring KIT exon 9 mutations and wild-type (wt) genotype than KIT exon 11 and PDGFR $\alpha$ mutations. ${ }^{23}$

\section{Third Line or Beyond-Regorafenib and Rechallenge with Imatinib}

Regorafenib, another oral multitargeted TKI, has activity against multiple kinases including KIT, RET, RAF1, BRAF, angiogeneisis (VEGFR and TEK), and those involved in tumor microenvironment (PDGFR and FGFR). Its biological activity against GIST and its ability to overcome the resistance to imatinib and sunitinib has recently confirmed in an international, multicenter, randomized (2:1), placebo-controlled phase III trial (GRID trial), ${ }^{24}$ which evaluated 199 highly refractory GIST patients who have previously failed at least imatinib and sunitinib. More than $40 \%$ of patients in each group had more than two lines of TKIs. This study showed a significant improvement in PFS (primary endpoint of the study) for patients receiving regorafenib compared with placebo (4.8 versus 0.9 months; HR=0.27, $95 \% \mathrm{Cl} 0.19-$ 0.39 ; $\mathrm{p}<0.0001)$, although OS benefit could not be demonstrated (HR 0.77, $95 \% \mathrm{Cl} 0.42-1.41 ; p=0.199)$ likely due to the crossover design of the trial. Treatment was reasonably well tolerated, with hypertension, hand-foot syndrome, and diarrhea being the most common grade $\geq 3$ adverse events, which could be managed by dose reduction and supportive treatments. Regorafenib is now approved in most jurisdictions as third-line treatment after imatinib and sunitinib.

The phenomenon of tumor flare upon withdrawal of TKIs, thought likely due to the loss of sensitive clonal control, in addition to the growth of resistant clones, is well described. This led to the idea of rechallenge of imatinib after failure of second/third-line TKIs. RIGHT ${ }^{25}$ was a randomized, double blind phase III trial, evaluating the efficacy of re-challenging progressing patients with imatinib in 81 patients who have failed with both imatinib and sunitinib. Similar to the GRID trial, there were $40 \%$ patients in each group who had received $>2$ lines of TKIS. A modest improvement in PFS (primary endpoint of the study) in patients receiving imatinib compared with placebo ( 1.8 versus 0.9 months; $\mathrm{HR}=0.46,95 \% \mathrm{Cl} 0.27-0.78 ; \mathrm{p}=0.005$ ) was seen. OS benefit was not seen (8.2 versus 7.5 months; $H R=1.00,95 \%$ $\mathrm{Cl} 0.58-1.83 ; \mathrm{p}=0.92$ ) again likely due to the crossover design of the trial.

\section{Adjuvant Therapy}

The role of adjuvant therapy in GIST is slowly becoming better defined, as there are now two phase III studies (North America and Europe) to support the use of adjuvant therapy in surgically R0/R1 (R0-complete resection defined as removal of all gross and microscopic disease; R1 microscopic margins) resected GIST. The use of imatinib adjuvant therapy in the high-risk population reduces disease recurrence and improves relapse-free survival (RFS). However, controversies exist in terms of the duration of adjuvant therapy, risk stratification system differences, its role in 'intermediate risk' patients, and the role of tumor mutational analysis.

The American College of Surgeons Oncology Group (ACOSOG) Z9000 trial26 was the first prospective study to establish the efficacy of adjuvant imatinib 
in surgically resected GIST. This single arm, open label, multicenter, phase II study evaluated 106 patients with a grossly complete resected (R1 and R0) KIT-positive GIST that were at high risk for disease recurrence, defined as tumor size $\geq 10 \mathrm{~cm}$, intraperitoneal tumor rupture, and/or up to four peritoneal implants. After an updated median follow-up (mF/U) of 7.7 years, the 1-, 3-, and 5-year OS and RFS rates were $99 \% / 96 \%, 97 \% / 60 \%$, and $83 \% / 40 \%$, respectively. ${ }^{26}$ These results compare favorably with the historical 5-year OS and recurrence rate of $35 \%$ and $54 \%$, respectively, for patients with resected GIST. ${ }^{27}$

These results led to the pivotal phase III ACOSOG 29001 (Alliance) trial28, a randomized, placebo-controlled, double-blind study conducted in North America. This study enrolled 713 patients with a RO/R1 resected primary GIST (size $>3 \mathrm{~cm}$ ) randomized to imatinib $(400 \mathrm{mg} /$ day) or placebo for 1 year, with a primary study outcome of RFS. It is important to note that crossover was permitted upon disease recurrence. A significant improvement in 1-year RFS in patients receiving imatinib (98\% versus $83 \%$; $\mathrm{HR}=0.35$ with a $95 \% \mathrm{Cl}$ [0.22-0.53]; one-sided $\mathrm{p}<0.0001$ ) with an $\mathrm{mF} / \mathrm{U}$ of $19.7(0-56)$ months observed. A subgroup analysis showed that tumors $\geq 10 \mathrm{~cm}$ derived the most clinical benefit. These results led to the US Food and Drug Administration (FDA) approval of imatinib in the adjuvant setting. It was notable that the $\mathrm{mF} / \mathrm{U}$ time was short due to the fact that the trial was stopped when primary objective was achieved at the time of interim analysis. There was no difference in OS rate between two groups

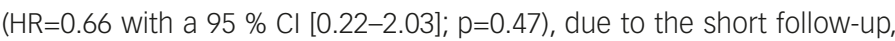
crossover design, nonstatistical power for OS, and the biological fact that 1 year of adjuvant therapy likely not sufficient to provide an OS benefit.

The significant RFS benefit of adjuvant imatinib has also been shown in multiple prospective studies in China, ${ }^{29,30}$ Japan, ${ }^{31}$ Korea, ${ }^{32}$ and Europe. ${ }^{33}$ The question of duration of adjuvant imatinib therapy has also been subsequently evaluated in some of these prospective Asian ${ }^{29,32}$ and European ${ }^{33}$ trials (see Table 2). A nonrandomized, cohort study of 105 Chinese patients with complete tumor resection with intermediate or high risk for recurrence (tumor size $>5 \mathrm{~cm}$ and/or mitotic $>5 / 50$ highpower fields [HPF]) showed treatment with imatinib $400 \mathrm{mg} /$ day for 3 years achieved a significant longer RFS at 1-, 2-, and 3-years compared with no treatment (100\% versus $90 \%$, $96 \%$ versus $57 \%$, $89 \%$ versus $48 \%$, respectively; $\mathrm{p}<0.0001$; HR $1 / 40.188$; $95 \% \mathrm{Cl} 0.085-0.417$ ), as well as OS (HR=0.254; $95 \% \mathrm{Cl} 0.070-0.931)$.

Another open-label, single-arm nonrandomized, multicenter phase II study conducted in Korea evaluated 47 patients with resected high-risk GIST (size $>10 \mathrm{~cm}$, or tumor size $>5 \mathrm{~cm}$ and mitotic $>5 / 50 \mathrm{HPF}$, or mitotic $>10 / 50 \mathrm{HPF}$ ) who received adjuvant imatinib $400 \mathrm{mg}$ /day for 2 years. A remarkable mRFS of 58.9 months with $\mathrm{mF} / \mathrm{U}$ of 27.7 months and 5-year survival of $97.9 \%$, was numerically better than the ACOSOG Z9000 phase II study conducted in US.

The EORTC62024 phase III tria|34 randomized resected GIST patients to 2 years of imatinib to observation in patients with completely resected intermediate- or high-risk GIST (tumor size $>5 \mathrm{~cm}$ and/or mitotic $>5 / 50$ HPF). The initial primary study endpoint was OS, which was changed to imatinib failure-free survival (IFS) to account for imatinib secondary resistance. However, this surrogate endpoint still needs to be prospectively validated. At an $\mathrm{mF} / \mathrm{U}$ of 4.7 years, 5 -year IFS was $87 \%$ in the imatinib arm compared with $84 \%$ in the observation arm (HR 0.80;
$95 \% \mathrm{Cl} 0.51-1.26$ ). The 5 -year OS was quite similar (100 \% versus $99 \%$ ). ${ }^{34}$ There was a nonstatistically significant trend toward the adjuvant arm in high-risk GIST patients using modified US National Institutes of Health $(\mathrm{NIH})$ criteria. ${ }^{34}$ The final data are still awaited to draw a firm conclusion.

The evidence supporting the use of adjuvant imatinib and longer duration in resected high-risk GIST came from the recently published randomized phase III Scandinavian Sarcoma Group and the Sarcoma Group of Arbeitsgemeinschaft Internistische Onkologie (SSGXVIII/AIO) trial conducted in Europe. ${ }^{32}$ This study compared 1 year versus 3 years of adjuvant imatinib therapy (400 mg/day) in patients with completely resected GIST with a high risk for recurrence. High risk was defined based on modified NIH criteria (tumor size $>10 \mathrm{~cm}$, or tumor size $>5 \mathrm{~cm}$ and mitotic $>5 / 50 \mathrm{HPF}$, or mitotic $>10 / 50 \mathrm{HPF}$, or tumor rupture before or at time of surgery). This trial not only confirmed a significant RFS benefit of 3 years compared with 1 year of adjuvant imatinib therapy (5-year RFS $65.6 \%$ versus $47.9 \%$, HR=0.46; $95 \%$ $\mathrm{Cl} 0.32-0.65 ; \mathrm{p}<0.001$ ), but also demonstrating a significant OS benefit of 3 years of adjuvant imatinib therapy compared with 1 year (5-year survival, $92.0 \%$ versus $81.7 \%$; $\mathrm{HR}=0.45 ; 95 \% \mathrm{Cl} 0.22-0.89 ; \mathrm{p}=0.02)$. This trial has led the National Comprehensive Cancer Network (NCCN) $)^{35}$ to update their guideline to recommend 3 years of adjuvant imatinib for patients with completely resected high-risk GIST. More recently, an economic modeling study paralleling the SSGXVIII/AIO trial showed cost-effectiveness of 3 years of adjuvant imatinib. ${ }^{36}$ Although this currently has become the standard of care, the precise duration of treatment remains undefined and likely will be similar to the question of duration of adjuvant hormone therapy in breast cancer. It seems that the duration of adjuvant therapy less than 3 years is not enough based on the ACOSOG Z9001, SSGXVIII/AIO, and the EORTC62024 trials. An ongoing phase I, nonrandomized, open-label, multicenter study Post-resection Evaluation of Recurrence-free Survival for Gastrolntestinal Stromal Tumors with adjuvant imatinib (PERSIST-5) will evaluate time to recurrence (TTR) and safety for 5 years of adjuvant imatinib for patients with completely resected intermediate- and high-risk GIST (tumor size $\geq 2$ $\mathrm{cm}$ and mitotic rate $\geq 5 / 50 \mathrm{HPF}$ at any site; for nongastric size $\geq 5 \mathrm{~cm}$ ). ${ }^{37}$

Although the currently available data strongly support use of adjuvant therapy in patients with resected GIST with a high risk for recurrence, the benefit of using adjuvant therapy in the intermediate risk group remains controversial. In addition, it should be noted that there are some distinct discrepancies in defining risk categories using the three most commonly used risk-stratification systems namely: 1) NIH Consensus (Fletcher) criteria, ${ }^{38}$ 2) the modified NIH (Joensuu) ${ }^{39}$ criteria, and 3) the NCCN-Armed Forces Institute of Pathology (NCCN-AFIP) criteria ${ }^{40}$ (see Table 3). The first widely accepted criteria were the $\mathrm{NIH}$ Consensus Criteria, ${ }^{38}$ which used tumor size and mitotic rate to define risk category. We now know that tumor location is also an independent prognostic factor to determine risk for recurrence, as gastric GIST is generally associated with better outcome compared with all others. The NCCN-AFIP criteria ${ }^{40}$ included tumor site in their nomogram. It is also noted that mitotic rate $>5 / 50 \mathrm{HPF}$ was considered as a high-risk category regardless of tumor size and location in the NCCNAFIP criteria. ${ }^{40}$ Rutkowski et al. ${ }^{41}$ established tumor rupture as another important high-risk feature to predict tumor recurrence regardless of tumor size, mitotic rate, or tumor location. This has subsequently been validated in modified NIH (Joensuu) criteria39. In addition, another important distinction between the Joensuu classification and the $\mathrm{NIH}$ Consensus Criteria is that tumor size $>5 \mathrm{~cm}$ or mitotic rate $>5 / 50 \mathrm{HPF}$ nongastric GISTS are 
Table 2: Major Clinical Trials of Adjuvant Imatinib on Completely Resected GIST

\begin{tabular}{|c|c|c|c|c|c|c|c|}
\hline Study & $\begin{array}{l}\text { Patient } \\
\text { Number }\end{array}$ & Inclusion Criteria & $\begin{array}{l}\text { Dose } \\
\text { (mg/day) }\end{array}$ & $\begin{array}{l}\text { Duration } \\
\text { (Year/s) }\end{array}$ & $\begin{array}{l}\text { Primary } \\
\text { Outcome }\end{array}$ & RFS & OS \\
\hline $\begin{array}{l}\text { DeMatteo et al. } \\
\text { updated in } 2013^{26} \\
\text { AcosoG Z9000 } \\
\text { phase II }\end{array}$ & 106 & $\begin{array}{l}\text { At least R1 resected } \\
\text { high risk defined as tumor } \\
\text { size } \geq 10 \mathrm{~cm} \text {, intraperitoneal } \\
\text { tumor rupture, or up to } 4 \\
\text { peritoneal implants }\end{array}$ & 400 & 1 & OS & $\begin{array}{l}\text { mRFS } 4.0 \mathrm{yrs} ; 96 \% \text { at } \\
1 \mathrm{yr} ; 60 \% \text { at } 2 \mathrm{yrs} ; \\
40 \% \text { at } 5 \mathrm{yrs} \text { with } \mathrm{mF} / \mathrm{U} \\
\text { of } 7.7 \mathrm{yrs}\end{array}$ & $\begin{array}{l}99 \% \text { at } 1 \mathrm{yr} ; 93 \% \text { at } 2 \mathrm{yrs} ; \\
83 \% \text { at } 5 \mathrm{yrs} \text { with } \mathrm{mF} / \mathrm{U} \text { of } \\
7.7 \mathrm{yrs}\end{array}$ \\
\hline $\begin{array}{l}\text { DeMatteo et al. } \\
2009^{28} \\
\text { ACOSOG Z } 9001 \\
\text { phase III }\end{array}$ & $\begin{array}{l}713 \\
359 \\
\text { (imatinib) } \\
\text { vs } 354 \\
\text { (placebo) }\end{array}$ & $\begin{array}{l}\text { At least } \mathrm{R} 1 \text { resected } \\
\text { tumor size } \\
\geq 3 \mathrm{~cm} \text { KIT mutation } \\
\text { positive }\end{array}$ & 400 & 1 & RFS & $\begin{array}{l}98 \% \text { vs } 83 \% \text { at } 1 \text { yr with } \\
\text { mF/U } 19.7 \text { mos ( } H R=0.35 \\
p<0.0001 \text { one side) }\end{array}$ & $\begin{array}{l}98.6 \% \text { vs } 97.7 \% \text { at } 2 y r s \\
(H R=0.66 ; p=0.47)\end{array}$ \\
\hline $\begin{array}{l}\text { Li et al. } 2011^{29} \\
\text { Prospective } \\
\text { cohort study }\end{array}$ & $\begin{array}{l}105 \\
56 \text { (imatinib) } \\
\text { vs } 49 \\
\text { (placebo) }\end{array}$ & $\begin{array}{l}\text { RO resected intermediate } \\
\text { and high risk based on } 2001 \\
\text { NIH criteria }\end{array}$ & 400 & 3 & RFS & $\begin{array}{l}100 \% \text { vs } 90 \% \text { at } 1 \text { yr; } 95 \% \\
\text { vs } 57 \% \text { at } 2 \text { yrs; } 89 \% \text { vs } 48 \% \\
\text { at } 3 \text { yrs, with mF } / \cup 45 \text { mos } \\
(\text { HR= } 0.188 ; p<0.001)\end{array}$ & $\begin{array}{l}\text { mos could not be obtained, } \\
\text { though significantly higher in } \\
\text { imatinib group ( } H R=0.254 \text {; } \\
p=0.025 \text { ) }\end{array}$ \\
\hline $\begin{array}{l}\text { Zhan et al. } 2007^{30} \\
\text { phase II }\end{array}$ & 51 & $\begin{array}{l}\text { At least R1 resected } \\
\text { high risk based on } 2001 \\
\text { NIH criteria }\end{array}$ & 400 & 1 & DFS & mDFs: 385 ds & NA \\
\hline $\begin{array}{l}\text { Kanda et al. } 2013^{31} \\
\text { phase II and IV }\end{array}$ & 64 & $\begin{array}{l}\text { At least R1 resected high } \\
\text { risk based on } 2001 \mathrm{NIH} \\
\text { criteria }\end{array}$ & 400 & 1 & RFS & $\begin{array}{l}71.1 \% \text { at } 2 \text { yrs and } 41.7 \% \\
\text { at } 3 \text { yrs at } \mathrm{mF} / \mathrm{U} 107 \mathrm{wks}\end{array}$ & $93.7 \%$ at $2 y r s$ \\
\hline $\begin{array}{l}\text { Joensuu et al. } \\
2012^{33} \\
\text { SSGXVIII/AIO } \\
\text { phase III }\end{array}$ & $\begin{array}{l}400 \\
\text { (imatinib } \\
200 \text { (imatinib } \\
\text { for } 1 \text { yr) vs } \\
200 \text { (imatinib } \\
\text { for } 3 \text { yrs) }\end{array}$ & $\begin{array}{l}\text { At least R1 resected high } \\
\text { risk based on modified } \\
\mathrm{NIH} \text { criteria }\end{array}$ & 400 & 1 vs 3 & RFS & $\begin{array}{l}65.5 \% \text { vs } 47.9 \% \text { at } 5 \text { yrs } \\
\text { with } \mathrm{mF} / \mathrm{U} 54 \mathrm{mos} \\
(\mathrm{HR}=0.46 ; p<0.001)\end{array}$ & $\begin{array}{l}92 \% \text { vs } 81.7 \% \text { at } \\
5 \text { yrs with } \mathrm{mF} / \cup 54 \text { mos } \\
(H R=0.45 ; p=0.02)\end{array}$ \\
\hline $\begin{array}{l}\text { Kang et al. } 2013^{32} \\
\text { phase II }\end{array}$ & 47 & $\begin{array}{l}\text { High risk based on } \\
2001 \text { NIH criteria and } \\
\text { KIT exon } 11 \text { mutations }\end{array}$ & 400 & 2 & RFS & $\begin{array}{l}\text { mRFS } 58.9 \text { mos with } \\
\text { mF/U } 27.7 \text { mos }\end{array}$ & $97.9 \%$ at 5 yrs \\
\hline $\begin{array}{l}\text { EORTC62024 } \\
\text { phase III } \\
\text { (ClinicalTrialsgov; } \\
\text { NCT00103168 } \\
\text { recruiting) }\end{array}$ & $\begin{array}{l}906 \\
\text { (target) }\end{array}$ & $\begin{array}{l}\text { At least R1 resected } \\
\text { intermediate and high } \\
\text { risk based on } 2001 \\
\text { NIH criteria }\end{array}$ & 400 & 2 & OS & NA & NA \\
\hline $\begin{array}{l}\text { PERSISIT-537 } \\
\text { phase II } \\
\text { (ClinicalTrialsgov; } \\
\text { NCT00867113 } \\
\text { recruiting) }\end{array}$ & $\begin{array}{l}91 \\
\text { (target) }\end{array}$ & $\begin{array}{l}\text { At least R1 resected } \\
\text { intermediate and high } \\
\text { risk defined as tumor } \\
\text { size } \geq 2 \mathrm{~cm} \text { and mitotic } \\
\text { rate } \geq 5 / 50 \text { HPF at any } \\
\text { site; for nongastric } \\
\text { size } \geq 5 \mathrm{~cm}\end{array}$ & 400 & 5 & $T T R$ & NA & NA \\
\hline
\end{tabular}

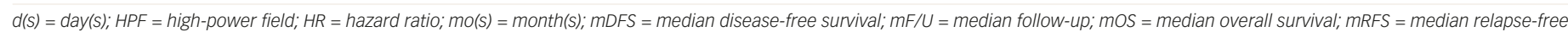
survival; $N I H=$ US National Institutes of Health; $T T R=$ time to recurrence; $y r(s)=$ year(s).

considered high-risk tumors in the Joensuu criteria, unlike in the Fletcher criteria. Joensuu criteria is likely the best criteria to identify a single highrisk group for consideration of adjuvant therapy. ${ }^{42}$ In our center, high risk is defined based on the Joensuu criteria, which was also used in seminal SSGXVIII/AIO trial.

It is well known that the GIST tumor mutation analysis has both prognostic and predictive value in adjuvant setting. Tumors carrying a KIT exon 9 mutation have the highest recurrence rate compared with KIT 11 mutation, wt, and PDGFR $\alpha$ sensitive mutation tumors (recurrence rate in descending order). Adjuvant imatinib appears to benefit the tumors with KIT exon 11 deletion mutations. This is supported by a recent study demonstrating that imatinib therapy was associated with higher RFS in patients with a KIT exon 11 deletion of any type, but not a KIT exon 11 insertion or point mutation, KIT exon 9 mutation, PDGFR $\alpha$ mutation, or wt tumor, although some of these patient groups were not well represented. ${ }^{43}$ This is consistent with many studies undertaken in the metastatic setting showing that a KIT 11 mutation and PDGFR $\alpha$ D82V mutation are the most imatinib-sensitive and resistant, respectively. An interesting tumor genotype has been shown in a multivariable analysis ${ }^{43}$ not significantly associated with RFS compared with tumor size, mitotic rate, and tumor location. Therefore, it remains debatable whether to the use of tumor mutation analysis in adjuvant setting to tailor treatment. In our center we do not routinely use tumor mutation analysis in the adjuvant setting as a prediction tool. 
Table 3: Comparison of Commonly Used Risk-stratification Systems for Resected Primary Localized GIST

\begin{tabular}{|c|c|c|c|}
\hline & $\mathrm{NIH}$ Consensus (Fletcher) Criteria ${ }^{38}$ & Modified NIH (Josensuu) Criteria ${ }^{39}$ & NCCN-AFIP Criteria ${ }^{40}$ \\
\hline Very low risk & $\begin{array}{l}\text { Any tumor site: primary tumor size } \leq 2 \mathrm{~cm} \\
\text { and mitotic rate } \leq 5 / 50 \mathrm{HPF}\end{array}$ & $\begin{array}{l}\text { Any tumor site: primary tumor size } \leq 2 \mathrm{~cm} \\
\text { and mitotic rate } \leq 5 / 50 \mathrm{HPF}\end{array}$ & $\begin{array}{l}\text { Gastric: primary tumor size } 2-5 \mathrm{~cm} \text { and mitotic } \\
\text { rate } \leq 5 / 50 \mathrm{HPF}\end{array}$ \\
\hline Low risk & $\begin{array}{l}\text { Any tumor site: primary tumor size } 2-5 \mathrm{~cm} \\
\text { and mitotic rate } \leq 5 / 50 \mathrm{HPF}\end{array}$ & $\begin{array}{l}\text { Any tumor site: primary tumor size } 2.1-5 \mathrm{~cm} \\
\text { and mitotic rate } \leq 5 / 50 \mathrm{HPF}\end{array}$ & $\begin{array}{l}\text { Gastric: primary tumor size } 5.1-10 \mathrm{~cm} \text { and mitotic } \\
\text { rate } \leq 5 / 50 \mathrm{HPF} \\
\text { Intestinal: primary tumor size } \leq 5 \mathrm{~cm} \text { and mitotic } \\
\text { rate } \leq 5 / 50 \mathrm{HPF}\end{array}$ \\
\hline Intermediate risk & $\begin{array}{l}\text { Any tumor site: primary tumor size } 5.1-10 \mathrm{~cm} \\
\text { or mitotic rate } 6-10 / 50 \mathrm{HPF}\end{array}$ & $\begin{array}{l}\text { Gastric: primary tumor size } 5.1-10 \mathrm{~cm} \text { or } \\
\text { mitotic rate } 6-10 / 50 \mathrm{HPF}\end{array}$ & $\begin{array}{l}\text { Gastric: primary tumor size }>10 \mathrm{~cm} \text { and mitotic } \\
\text { rate } \leq 5 / 50 \mathrm{HPF} \\
\text { Intestinal: primary tumor size } 5.1-10 \mathrm{~cm} \text { and } \\
\text { mitotic rate } \leq 5 / 50 \mathrm{HPF}\end{array}$ \\
\hline High risk & $\begin{array}{l}\text { Any tumor site: primary tumor size }>10 \mathrm{~cm} \\
\text { or mitotic rate }>10 / 50 \mathrm{HPF} \text { or primary tumor } \\
\text { size }>5 \mathrm{~cm} \text { and mitotic rate }>5 / 50 \mathrm{HPF}\end{array}$ & $\begin{array}{l}\text { Any tumor site: primary tumor size }>10 \mathrm{~cm} \\
\text { or mitotic rate }>10 / 50 \mathrm{HPF} \text { or primary tumor } \\
\text { size }>5 \mathrm{~cm} \text { and mitotic rate }>5 / 50 \mathrm{HPF} \text { or } \\
\text { tumor rupture } \\
\text { Nongastric site: primary tumor size } \\
>5 \mathrm{~cm} \text { or mitotic rate }>5 / 50 \mathrm{HPF} \text { or } \\
\text { tumor rupture }\end{array}$ & $\begin{array}{l}\text { Gastric: primary tumor size }>5 \mathrm{~cm} \text { and mitotic } \\
\text { rate }>5 / 50 \mathrm{HPF} \\
\text { Intestinal: primary tumor size }>10 \mathrm{~cm} \text { and mitotic } \\
\text { rate } \leq 5 / 50 \mathrm{HPF} \\
\text { Any tumor site: mitotic rate }>5 / 50 \mathrm{HPF}\end{array}$ \\
\hline
\end{tabular}

GIST = gastrointestinal stromal tumor; HPF = high-power field; NCCN-AFIP = National Comprehensive Cancer Network-Armed Forces Institute of Pathology; NIH = US National Institutes of Health.

Table 4: Major Clinical Trials and Retrospective Studies on Preoperative/Neoadjuvant Imatinib in Primary Locally Advanced or Recurrent/Metastatic GIST

\begin{tabular}{|c|c|c|c|c|c|c|c|c|}
\hline Study & $\begin{array}{l}\text { Patient } \\
\text { Number and } \\
\text { Tumor Type }\end{array}$ & $\begin{array}{l}\text { Tumor Size } \\
\text { Median } \\
\text { (Range, cm) }\end{array}$ & $\begin{array}{l}\text { Imatinib } \\
\text { Dose } \\
\text { (mg/day) }\end{array}$ & $\begin{array}{l}\text { Imatinib } \\
\text { Duration } \\
\text { Median (Range) }\end{array}$ & $\begin{array}{l}\text { Response } \\
\text { Rate (\%) }\end{array}$ & $\begin{array}{l}\text { R0 Resection } \\
\text { Rate (\%) }\end{array}$ & $\begin{array}{l}\text { DFS (primary) } \\
\text { or PFS (recurrent/ } \\
\text { Metastatic) }\end{array}$ & OS (DSOS) \\
\hline \multirow[t]{2}{*}{$\begin{array}{l}\text { Eisenberg et al. } \\
2009,44 \\
201245 \\
\text { phase II }\end{array}$} & 31 primary & $>5$ & 600 & $\begin{array}{l}2.13 \text { (2-3) mos } \\
\text { Adjuvant: } \\
400 \mathrm{mg} / \mathrm{d} \text { for } \\
2 \mathrm{yrs}\end{array}$ & $\begin{array}{l}7 \% \text { PR; } \\
83 \% \text { SD; } \\
10 \% \text { unknown }\end{array}$ & $77 \%$ & $\begin{array}{l}83 \% \text { at } 2 y r s ; \\
57 \% \text { at } 5 \text { yrs }\end{array}$ & $\begin{array}{l}93 \% \text { at } 2 \mathrm{yrs} ; \\
77 \% \text { at } 5 \mathrm{yrs}\end{array}$ \\
\hline & $\begin{array}{l}22 \text { recurrent/ } \\
\text { metastatic }\end{array}$ & $>2$ & & & $\begin{array}{l}3.5 \text { \% PR; } 91 \text { \% } \\
\text { SD; } 4.5 \% \text { PD }\end{array}$ & $58 \%$ & $\begin{array}{l}77 \% \text { at } 2 \mathrm{yrs} ; \\
30 \% \text { at } 5 \mathrm{yrs}\end{array}$ & $\begin{array}{l}91 \% \text { at } 2 \mathrm{yrs} ; \\
68 \% \text { at } 5 \mathrm{yrs}\end{array}$ \\
\hline $\begin{array}{l}\text { McAuliffe } \\
\text { et al. 2009, }{ }^{46} \\
\text { randomized } \\
\text { phase II }\end{array}$ & 19 primary & NA & 600 & $\begin{array}{l}3,5, \text { or } 7 \mathrm{ds} \\
\text { Adjuvant for } \\
2 \text { yrs }\end{array}$ & $\begin{array}{l}\text { RR: } 69 \% \text { by } \\
\text { dynamic CT } \\
71 \% \text { by PET }\end{array}$ & NA & $\begin{array}{l}87 \% \text { at } 2 \text { yrs } \\
\text { mDFS } 46 \text { mos } \\
\text { at mF/U } 32 \text { mo }\end{array}$ & NA \\
\hline $\begin{array}{l}\text { Doyon et al. } \\
2012,{ }^{47} \\
\text { phase II }\end{array}$ & 14 primary & $9.4(1.7-17.3)$ & $\begin{array}{l}400 \text { in } 7 \text { pts, } \\
600 \text { in } 7 \text { pts } \\
\text { due to } \\
\text { nonresponse } \\
\text { at } 9 \text { wks }\end{array}$ & $9(2-12)$ & $\begin{array}{l}\text { PR: } 43 \% \\
\text { SD: } 57 \%\end{array}$ & $78 \%$ & $64 \%$ at 4 yrs & $100 \%$ at 4 yrs \\
\hline $\begin{array}{l}\text { Hohenberger } \\
\text { et al. 2012,48 } \\
\text { phase II }\end{array}$ & 40 primary & 10.8 & $\begin{array}{l}400 \text { or } \\
800 \text { (exon 9) }\end{array}$ & $4-6$ & NA & $88.2 \%$ & $85.2 \%$ at 3 yrs & $100 \%$ at 3 yrs \\
\hline $\begin{array}{l}\text { Bleslus } \\
\text { et al. 2011,49 } \\
\text { retrospective } \\
\text { substudy of } \\
\text { phase III }\end{array}$ & 25 primary & 15 & 400 & $7.3(3.4-12)$ & $\begin{array}{l}\text { PR: } 60 \% \\
\text { SD: } 28 \% \\
\text { PD:12 \% }\end{array}$ & $77 \%$ & $67 \%$ at 3 yrs & $89 \%$ at 3 yrs \\
\hline
\end{tabular}

\section{Neoadjuvant Therapy}

A summary of clinical trials can be found in Table 4. There is a lack of phase III clinical trial data to define the precise roles of neoadjuvant therapy in locally advanced primary GIST or recurrent/metastatic GIST. Neoadjuvant therapy is generally viewed as a reasonable option for tumor downstaging, and helps reduce short- and long-term surgical morbidities, resulting in organ preservation/function, and achieve microscopic Ro resection for marginally operable GIST tumors. The safety and efficacy of neoadjuvant imatinib has been established in several prospective and retrospective studies. ${ }^{44-50}$ Preoperative use of imatinib is recommended in the updated European 
Society of Medical Oncology (ESMO) $)^{51}$ as well as the NCCN guidelines ${ }^{35}$ in patients with resectable GIST, but is associated with significant surgical morbidity. However, several questions remain unanswered: 1) Should we choose the optimal dose of imatinib based on tumor mutational analysis in the setting of neoadjuvant treatment? 2) What is the optimal duration of neoadjuvant treatment with imatinib? 3) What are the optimal imaging modality or response criteria that should be used in the preoperative setting to evaluate the maximum or plateau tumor response?

RTOG 0132/ACRIN666544 was the first multi-institutional prospective phase II trial that evaluated neoadjuvant imatinib at $600 \mathrm{mg} /$ day for 8 to 12 weeks prior to resection in locally advanced primary $(\geq 5 \mathrm{~cm})$ and operable metastatic GIST ( $\geq 2 \mathrm{~cm}$ ) followed by postoperative adjuvant therapy for 2 years. For patients with only a primary GIST, the majority of patients had stable disease (stable disease [SD] $83 \%$ ), $7 \%$ had a partial response (PR) and no patients experienced progression using standard Response Evaluation Criteria in Stromal Tumors (RECIST) criteria. ${ }^{52}$ In this study, Ro resection rate was achieved in most patients (77\%). The estimated 2- and 5-year disease-free survival (DFS) is 77\% and $53 \%$, respectively; the estimated 2- and 5-year OS is $97 \%$ and $77 \%$, respectively. ${ }^{45}$ The rationale for choosing 8 to 12 weeks as the duration of imatinib in this study is based on medial time to PR to imatinib in metastatic setting at time. ${ }^{4}$ The low response rate in this study is likely compounded by the insensitivity of standard RECIST criteria in evaluating imatinib-treated GIST given that the metabolic response to imatinib as measured by fludeoxyglucose-positron emission tomography (FDG-PET) scan in the separate analysis of the same phase II study was $85 \%$. $^{53}$ This metabolic response can be seen as early as 7 days especially in exon 11 mutation-positive GIST tumors. ${ }^{53}$ The well-documented evidence of early response detection as assessed by PET scan compared with standard RECIST is noteworthy, especially in the context of early studies reporting that more than 3 months was required before a PR as defined by standard RECIST criteria was met.

A second neoadjuvant study published by McAuliffe et al. ${ }^{46}$ also demonstrated a remarkable response rate based on PET imaging. In this phase II study, 19 patients were randomized to receive a brief course of neoadjuvant imatinib (300 $\mathrm{mg}$ bid for 3, 5, or 7 days) prior to surgery followed postoperatively by 2 years of adjuvant imatinib. The reason for choosing to treat patients for a short course of imatinib for 3,5 , or 7 days was to show that molecular measurement of cellular death can be detected much earlier than detectable histopathologic cytoreduction. The primary endpoint was tumor apoptosis, and correlations were made to radiographic responses. PET response, defined as absolute standardized uptake value (SUV) of 3.9 or less or $40 \%$ reduction was reported as $71 \%$, and the dynamic standardized uptake value computed tomography (CT) response, defined as a $>10 \%$ decrease in blood flow within a viable tumor was $69 \%$. Interestingly, correlation of radiographic responses (PET and/or dynamic CT) with pathologic tumor response (apoptosis) was not observed. This study also demonstrated that tumor response measured by radiographic imaging, as well as tumor cell apoptosis can occur within the first week of neoadjuvant imatinib therapy. The mDFS was 46 months (range 10-46 months, mF/U of 32 months); DFS at 2 years was $87 \%$.

Although PET scanning has been proved to be highly sensitive in early assessment of GIST tumor response to imatinib especially when early prediction of response is useful in situations such as preoperative cytoreductive treatments, the utility of PET scans in preoperative setting is less clear. There are no randomized data supporting use of this image modality versus traditional CT scans. In addition, the metabolic response evaluated by PET scan seems to poorly correlate with pathologic response as seen in the above study. In addition, another study showed that the complete metabolic response seen on PET scan offers only $17 \%$ chance for pathologic CR. ${ }^{54}$ Choi et al. ${ }^{55}$ recently published CT criteria to define tumor response to imatinib based on a combination of the values of tumor size and tumor density on $\mathrm{CT}$, which is a $10 \%$ decrease in tumor size or a more than $15 \%$ decrease in tumor density at 2 months of treatment. This modified CT response evaluation criteria had a sensitivity of $97 \%$ and a specificity of $100 \%$ in identifying PET responders compared with $52 \%$ and $100 \%$ by RECIST criteria, respectively. ${ }^{55}$ Furthermore, this study demonstrated that this criteria seems to better correlate with clinical outcomes than standard RECIST criteria, at least in imatinib-treated GIST. ${ }^{56}$

In our center, we prefer to use standard CT imaging to evaluate preoperative imatinib-treated patients based on the choi criteria. We treat patients with imatinib in the preoperative setting until maximal tumor response as defined by stable CT measurement, which is usually between 6 and 12 months. This approach is safe and efficacious, supported by a more recent Canadian multicenter nonrandomized phase II clinical trial ${ }^{47}$ performed by Doyon et al. and many other prospective and retrospective studies listed in Table 1. Doyon's phase II study evaluated 14 patients with marginally resectable primary GIST who were giving preoperative imatinib 400 mg until maximum tumor response (up to 1 year) followed by en bloc resection. The median duration of treatment was 9 months (2-12 months). R0 resection rate was $78 \%$ similar to the rate reported by RTOG 0132/ACRIN6665.44 According to the RECIST criteria, the PR rate was $43 \%$ and SD rate was $57 \%$. After a median follow-up of 48 months, 4-year OS and DFS were $100 \%$ and $64 \%$, respectively.

In a retrospective subanalysis of the BFR14 trial, ${ }^{49}$ which prospectively studied interrupted versus continuous imatinib in 434 patients with advanced GIST, 25 patients were identified with nonmetastatic primary GIST. Fifteen (60\%) had a PR and nine (36\%) went on to resection. Of those nine patients, median preoperative imatinib treatment duration was 7.3 (range 3.4-12) months, and seven (77\%) had an Ro resection, which is comparable with the rate reported by previous studies. Outcomes in patients who had surgery following preoperative imatinib were comparable with those with localized intermediate and high-risk GIST in the subgroup of operated patients, whereas those who did not undergo surgery behaved similarly to those with metastatic GIST. Although this result needs to be interpreted cautiously as selection bias does exist in this retrospective analysis. Patients who responded well to imatinib were more likely to be able to proceed to surgery and therefore had much better outcomes than those who did not.

In a study of radiologic assessment of response of GIST tumors to neoadjuvant imatinib prior to successful surgical resection, the plateau in the imatinib treatment response, defined as $<10 \%$ reduction in longest axial diameter on two consecutive CT scans beyond the best response, was seen at a median interval of 34 weeks (range, 26-41 weeks) and correlated with $45 \%$ (range, 35-45\%) tumor shrinkage. ${ }^{57}$ This is consistent with the literature and our experience. There is general consensus that there is little benefit of continuing imatinib beyond maximal response in terms of 


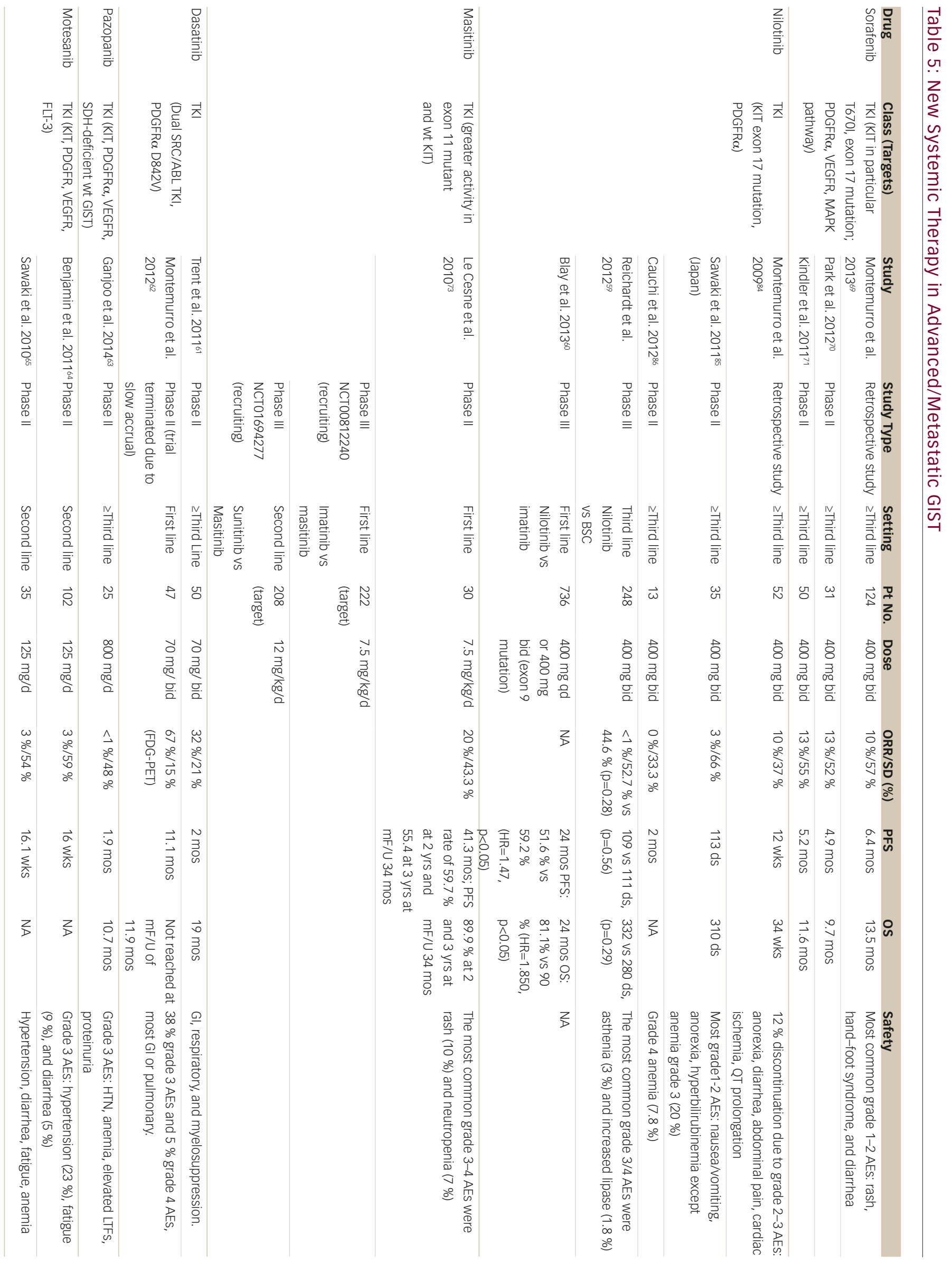




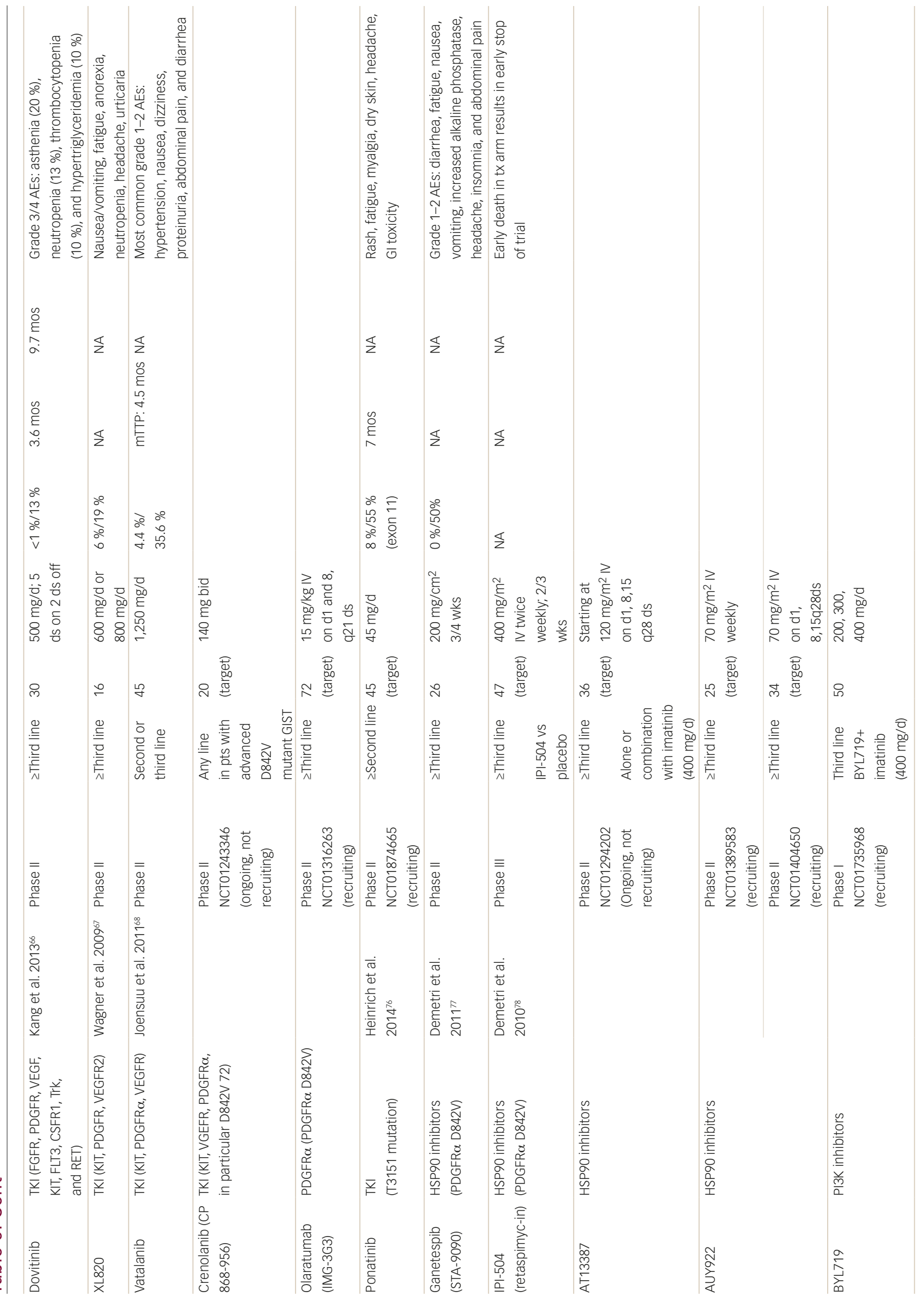




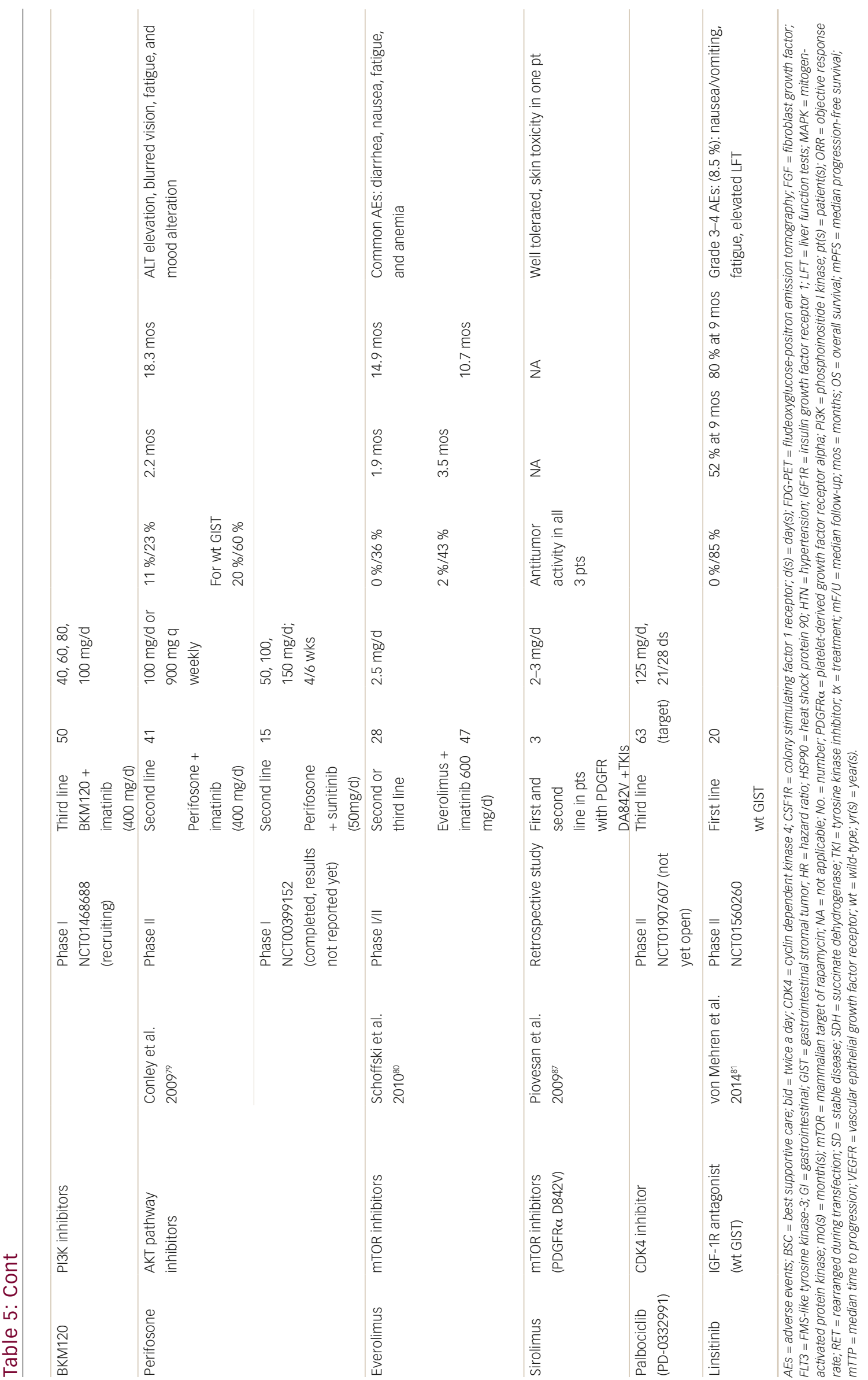


changing the scope of the planned operation and there is a suggestion of harm for prolonged neoadjuvant treatment ( $>1$ year) with imatinib. A recent retrospective study from MD Anderson Cancer Center ${ }^{58}$ found that duration of neoadjuvant therapy $>365$ days is significantly associated with higher risk for disease recurrence in patients with primary GIST suggesting that prolonged neoadjuvant therapy with imatinib greater than 12 months should be discouraged, although this was on univariate analysis only.

The dose of imatinib used in the preoperative setting has been either $400 \mathrm{mg}$ or $600 \mathrm{mg}$ daily in most prospective and retrospective studies. ${ }^{44-50}$ There is no convincing evidence supporting tumor mutational analysis to guide the neoadjuvant use of imatinib despite its known prognostic and predictive value in adjuvant and metastatic setting. Whether a higher dose should be considered in tumors associated with relative imatinib resistance such as small bowel GIST harboring an exon 9 mutation is uncertain.

\section{New Agents}

Currently there are no approved systemic treatments after imatinib, imatinib dose escalation, sunitinib, regorafenib, and rechallenging with imatinib. There are, however, many other oral multitargeted TKIS (sorafinib, nilotinib, masitinib, dasatinib, pazopanib, motasenib, dovitinib, $\mathrm{XL820}$, and ponatinib) and other molecular targeted agents such as heat shock protein 90 (HSP90) inhibitors, phosphoinositide 3-kinase (PI3K) inhibitor, and mammalian target of rapamycin (mTOR) inhibitors that have been tried or are currently in early phase I and II trials (see Table 5).

Unfortunately, unlike in chronic myelogenous leukemia (CML), Nilotinib, a second-generation KIT and PDGFR $\alpha$ inhibitor, tested in two phase III trials ${ }^{59,60}$ failed to show its efficacy in both the first- and third-line, or beyond, setting. Similarly, other TKIs such as dasatinib, ${ }^{61,62}$ pazopanib, ${ }^{63}$ motesanib, ${ }^{64,65}$ dovitinib, ${ }^{66} \mathrm{XL}^{2} 20,{ }^{67}$ and vatalanib ${ }^{68}$ have been tried in early phase trials in different settings. Unfortunately results have been disappointing (see Table 5).

\section{Tyrosine Kinase Inhibitors}

Sorafenib is a multityrosine kinase inhibitor with activity against KIT, PDGFR $\alpha$, and many other kinases. One retrospective study ${ }^{69}$ and two phase $\|$ studies ${ }^{70,71}$ have demonstrated its activity in patients with GIST who progressed on at least imatinib and sunitinib. Two-thirds of patients exhibited at least SD and mPFS of approximately 5 months, which are both comparable with what has been reported for regorafenib. The reported toxicity profiles of sorafenib were similar to regorafenib as well. Although we do not have phase III trials to confirm the above results.

Masatinib is another oral TKI with greater activity (lower IC50S) than imatinib against KIT exon 11 mutant and wt GIST in vitro. ${ }^{72}$ In a phase ॥ study, ${ }^{73}$ masatinib was tested in TKI naïve GIST patients. It demonstrated a similar response rate (RR) and disease control rate to imatinib. More impressively, about $60 \%$ of patients have SD at 2 years with an mPFS of 41.3 months. Therefore, masatinib is currently actively testing in the phase III trials in both the first- and second-line compared with imatinib and sunitinib, respectively.

Crenolanib is a potent imatinib-resistant PDGFR kinase inhibitor and has activity against PDGFR $\alpha$ D842V mutant GIST, which is found in approximately $5 \%$ of GIST patients that have complete resistance to imatinib. ${ }^{74}$ It is currently being tested in GIST patients with this particular mutation in a phase II trial (clinicalTrials.gov; NCT01243346).

Olaratumab is a monoclonal antibody specifically against PDGFR, including the PDGFR $\alpha 842$ V mutation, is also being tested in a phase II study (clinicalTrials.gov; NCT01316263).

Ponatinib is a novel kinase inhibitor structurally designed to target the T315I mutation in the ABL kinase domain..$^{75}$ It also has activity against KIT and PDGFR $\alpha$ secondary mutations. In the most recent pilot report of an ongoing phase II trial (clinicalTrials.gov; NCT01874665), which tested this drug in imatinib-resistant GIST patients, it demonstrated promising activity in this population with mPFS of 7 months, quite similar to sunitinib in the secondline setting, with manageable side effects. Interestingly, this study also demonstrated that ponatinib significantly inhibits KIT secondary mutation in two of the PR patients ex vivo.76

\section{Other New Agents}

HSP90 is a chaperone protein that protects mutant KIT/PDGFR. Therefore, inhibitors of HSP9O are theoretically active against KIT/PDGFR mutants regardless of the secondary mutations. In a phase II trial, ${ }^{77}$ Ganetespib (STA9090) showed only modest activity with a $0 \%$ RR and $50 \%$ SD in GIST patients who failed TKIs in the third line or beyond setting. The only phase III trial using another HSP90 inhibitor-IPI-504 (retaspimycin)—has been closed early due to toxicity in the treatment arm. ${ }^{78}$ Other less-toxic HSP90 inhibitors such as AT13387 (clinicalTrials.gov; NCT01294202) and AUY922 (clinicalTrials.gov; NCT01389583 and NCT01404650) are still being tested in early phase trials.

PI3K/AKT/mTOR are known downstream targets of KIT and PDGFR $\alpha$ pathways. Several inhibitors have been tested in early phase II trials, such as perifosone (AKT inhibitor) ${ }^{79}$ and everolimus (mTOR inhibitor), ${ }^{80}$ in combination with imatinib or sunitinib in the second- or third-line setting. They unfortunately did not show superior efficacy and had increased toxicities. Other PI3K inhibitors, such as BYL719 (clinicalTrials.org; NCT01735968) and BKM120 (clinicalTrials.org; NCT01468688), are currently being tested in phase I trials.

Linsitinib is an insulin-like growth factor receptor 1 (IGFR1) antagonist, which shows promising activity in wt GIST (15\% GIST in adults; $85 \%$ in children) due to high expression of IGFR in wt GIST most likely as a result of loss of succinate dehydrogenase (SDH) function. In a recent report of a phase II trial, 81 linsitinib achieved $80 \%$ SD in wt GIST patients with more than half of these patients disease controlled at 9 months, despite no objective response observed.

Palbociclib (PD-0332991) is a potent and selective cyclin-dependent kinase 4/6 (CDK4/6) inhibitor that targets cell cycle machinery. It has been extensively studied in endocrine resistant breast cancer, ${ }^{82}$ and shows some activity in liposarcoma. ${ }^{83} \mathrm{It}$ is planned to be tested in a phase II trial (clinicalTrials.org; NCT01907607) in GIST in the third-line setting.

\section{Conclusions}

Systemic treatments for GIST have advanced dramatically over a relatively short time period. Imatinib has been successfully used in the neoadjuvant setting to downstage tumors and reduce surgical morbidities, as well as the adjuvant setting to improve both DFS, as well as OS. With the use of 
imatinib, sunitinib, and regorafenib to treat advanced/metastatic GISTs in the first-, second- and third-line, respectively, mOS in stage IV GIST is 5 years and $20-30 \%$ patients with advanced disease are still alive over 10 years. There are many newer agents in the pipeline to be tested, some of them have shown promising results especially in specific subtypes of GIST and in GIST with secondary mutations. With these newer agents, hopefully we can further improve the already significant advances in the clinical outcomes of patients with advanced GIST in the near future.
1. Miettinen $\mathrm{M}$, Lasota J, Gastrointestinal stromal tumors-definition, clinical, histological, immunohistochemical, and molecular genetic features and differential diagnosis, Virchows Arch 2001;438:1-12

2. Hirota S, Isozaki K, Moriyama Y, et al., Gain-of-function mutations of c-kit in human gastrointestinal stromal tumors, Science, 1998;279:577-80

3. Joensuu H, Roberts PJ, Sarlomo-Rikala M, et al.. Effect of the tyrosine kinase inhibitor STI571 in a patient with a metastatic gastrointestinal stromal tumor N Eng/ I Med, 2001:344:1052-6.

4. Demetri GD, von Mehren $M$, Blanke CD, et al., Efficacy and safety of imatinib mesylate in advanced gastrointestinal stroma tumors, N Eng/ J Med, 2002;347:472-80.

5. Blanke $C D$, Demetri $G D$, von Mehren $M$, et al., Long-term results from a randomized phase II trial of standard- versus higher-dose imatinib mesylate for patients with unresectable or metastatic gastrointestinal stromal tumors expressing KIT, J Clin Oncol , 2008:26:620-5.

6. Verweij J, Casali PG, Zalcberg J, et al., Progression-free survival in gastrointestinal stromal tumours with high-dose imatinib: randomised trial, Lancet, 2004;364:1127-34.

7. Blanke $C D$, Rankin $C$, Demetri $G D$, et al., Phase III randomized, intergroup trial assessing imatinib mesylate at two dose levels in patients with unresectable or metastatic gastrointestinal stromal tumors expressing the kit receptor tyrosine kinase: s0033, J Clin Oncol, 2008:26:626-32.

8. Zalcberg JR, Verweij J, Casali PG, et al., Outcome of patients with advanced gastro-intestinal stromal tumours crossing over to a daily imatinib dose of $800 \mathrm{mg}$ after progression on $400 \mathrm{mg}$ Eur J Cancer, 2005;41:1751-7.

9. Le Cesne A, Ray-Coquard I, Bui BN, et al., Discontinuation of imatinib in patients with advanced gastrointestinal stromal tumours after 3 years of treatment: an open-label multicentre randomised phase 3 trial, Lancet Oncol, 2010:11:942-9.

10. Patrikidou A, Chabaud S, Ray-Coquard I, et al., Influence of imatinib interruption and rechallenge on the residual disease in patients with advanced GIST: results of the BFR14 prospective French Sarcoma Group randomised, phase III trial, Ann Oncol, 2013;24:1087-93.

11. Blanke $C D$, Benjamin $R$, Long-term survival on S0033-a phase III randomized, intergroup trial assessing imatinib mesylate at two dose levels in patients with unresectable or metastatic gastrointestinal stromal tumours (GISTS). European Multidisciplinary Cancer Congress. Stockholm, Sweden; September 23-27, 2011

12. Demetri GD, Rankin $\mathrm{CJ}$, Benjamin RS, et al., Long-term disease control of advanced gastrointestinal stromal tumors (GIST) with imatinib (IM): 10-year outcomes from SWOG phase III intergroup trial S0033. ASCO; 2014; Chicago, J Clin Oncol, 2014;32:5s.

13. Mazzeo F, Duck L, Joosens $E$, et al., Nonadherence to imatinib treatment in patients with gastrointestinal stromal tumors: the ADAGIO study, Anticancer Res, 2011:31:1407-9.

14. Hauber AB, Gonzalez JM, Coombs J, et al., Patient preferences for reducing toxicities of treatments for gastrointestinal stroma tumor (GIST), Patient Prefer Adherence, 2011;5:307-14.

15. Halpern R, Barghout V, Williams D, Relationship between compliance with imatinib mesylate and medical costs forpatients with CML and GIST. ASCO, Chicago, I Clin Oncol, (Meet Abstr), 2007.

16. Feng $X$, Morisky D, Mulder $K$, et al., A prospective observationa study of adherence to oral tyrosine kinase inhibitors (TKIS) in gastrointestinal stromal tumor (GIST). Canadian Association of Medical Oncology (CAMO) Annual Meeting, Toronto, 2014.

17. Al-Barrak J, Cheung WY, Adherence to imatinib therapy in gastrointestinal stromal tumors and chronic myeloid leukemia, Support Care Cancer, 2013:21:2351-7.

18. Demetri $G D$, Wang $Y$, Wehrle $E$, et al., Imatinib plasma levels are correlated with clinical benefit in patients with unresectable/ metastatic gastrointestinal stromal tumors, J Clin Oncol 2009;27:3141-7

19. Sawaki $A$, Hayashi $K$, Kanie $H$, et al., Imatinib plasma concentrations during long-term effective treatment of metastatic gastrointestinal stromal tumor. ASCO; 2007; Chicago, J Clin Oncol; 2013:31(Suppl.; abstr. 10543).

20. Demetri GD, van Oosterom AT, Garrett CR, et al., Efficacy and safety of sunitinib in patients with advanced gastrointestinal stromal tumour after failure of imatinib: a randomised controlled trial, Lancet, 2006;368:1329-38.

21. George S, Blay JY, Casali PG, et al., Clinical evaluation of continuous daily dosing of sunitinib malate in patients with advanced gastrointestinal stromal tumour after imatinib failure Eur J Cancer, 2009:45:1959-68.

22. Li J, Gao J, Hong J, Shen L, Efficacy and safety of sunitinib in Chinese patients with imatinib-resistant or -intolerant gastrointestinal stromal tumors, Future Oncol, 2012;8:617-24.

23. Rutkowski P, Bylina E, Klimczak A, et al., The outcome and predictive factors of sunitinib therapy in advanced gastrointestinal stromal tumors (GIST) after imatinib failureone institution study, BMC Cancer, 2012;12:107.

24. Demetri GD, Reichardt $P$, Kang $Y K$, et al., Efficacy and safety of regorafenib for advanced gastrointestinal stromal tumours after failure of imatinib and sunitinib (GRID): an international, multicentre, randomised, placebo-controlled, phase 3 trial, Lancet, 2013;381:295-302.

25. Kang YK, Ryu MH, Yoo C, et al., Resumption of imatinib to control metastatic or unresectable gastrointestinal stromal tumours after failure of imatinib and sunitinib (RIGHT): a randomised, placebo-controlled, phase 3 trial, Lancet Oncol, 2013;14:1175-82

26. DeMatteo RP, Ballman KV, Antonescu CR, et al., Long-term results of adjuvant imatinib mesylate in localized, high-risk, primary gastrointestinal stromal tumor: ACOSOG Z9000 (Alliance) intergroup phase 2 trial, Ann Surg, 2013;258(3):422-9.

27. DeMatteo RP, Lewis JJ, Leung D, et al., Two hundred gastrointestinal stromal tumors: recurrence patterns and prognostic factors for survival, Ann Surg, 2000;231:51-8.

28. DeMatteo RP, Ballman KV, Antonescu CR, et al., Adjuvant imatinib mesylate after resection of localised, primary gastrointestinal stromal tumour: a randomised, double-blind placebo-controlled trial, Lancet, 2009:373:1097-104.

29. Li J, Gong JF, WU AW, Shen L, Post-operative imatinib in patients with intermediate or high risk gastrointestinal stromal tumor, Eur J Surg Oncol, 2011;37:319-24.

30. Zhan WH, Efficacy and safety of adjuvant post-surgical therapy with imatinib in patients with high risk of relapsing GIST Journal of Clinical Oncology, 2007 ASCO Annual Meeting Proceedings (Post-Meeting Edition); 2007; 2007.

31. Kanda T, Nishida T, Wada N, et al., Adjuvant therapy with imatinib mesylate after resection of primary high-risk gastrointestinal stromal tumors in Japanese patients, Int J Clin Oncol, 2013:18:38-45.

32. Kang YK, Kang BW, Im SA, et al., Two-year adjuvant imatinib mesylate after complete resection of localized, high-risk GIST with KIT exon 11 mutation, Cancer Chemother Pharmacol, 2013;7:43-51.

33. Joensuu H, Eriksson M, Sundby Hall K, et al., One vs three years of adjuvant imatinib for operable gastrointestinal stromal tumor a randomized trial, JAMA, 2012; 307:1265-72.

34. Casali PG, Le Cesne A, Velasco AP, Imatinib failure-free survival in patients with localized gastrointestinal stromal tumors treated with adjuvant imatinib: the EORTC/AGITG/FSG/GEIS/ISG randomized controlled Phase III trial, ASCO 2013. Chicago, J Clin Oncol, 2013; (suppl; abstr 10500):31.

35. von Mehren M, Benjamin RS, Bui MM, et al., Soft tissue sarcoma, version 2.2012: featured updates to the NCCN guidelines, I Nat Compr Canc Netw, 2012:10:951-60

36. Majer IM, Gelderblom $H$, van den Hout WB, et al., Costeffectiveness of 3-year vs 1-year adjuvant therapy with imatinib in patients with high risk of gastrointestinal stromal tumour recurrence in the Netherlands; a modelling study alongside the SSGXVIII/AIO trial, I Med Econ, 2013;16:1106-19.

37. Novartis Pharmaceuticals. Five Year Adjuvant Imatinib Mesylate (Gleevec $($ ) in Gastrointestinal Stromal Tumor (GIST) ClinicalTrialsgov; NCT00867113 (accessed May 19, 2014).

38. Fletcher CD, Berman JJ, Corless C, et al., Diagnosis of gastrointestinal stromal tumors: A consensus approach, Hum Pathol 2002;33:459-65.

39. Rutkowski $P$, Bylina $E$, Wozniak A, et al., Validation of the Joensu risk criteria for primary resectable gastrointestinal stromal tumour - the impact of tumour rupture on patient outcomes, Eur J Surg Oncol, 2011;37:890-6.

40. Miettinen M, Lasota J, Gastrointestinal stromal tumors: pathology and prognosis at different sites, Semin Diagn Pathol, 2006:23:70-83.

41. Rutkowski P, Nowecki ZI, Michej W, et al., Risk criteria and prognostic factors for predicting recurrences after resection of primary gastrointestinal stromal tumor, Ann Surg Oncol, 2007;14:2018-27

42. Joensuu $H$, Vehtari $A$, Riihimaki J, et al., Risk of recurrence of gastrointestinal stromal tumour after surgery: an analysis of pooled population-based cohorts, Lancet Oncol, 2012:13:265-74.

43. Corless CL, Ballman KV, Antonescu CR, et al., Pathologic and molecular features correlate with long-term outcome after adjuvant therapy of resected primary GI stromal tumor: the ACOSOG Z9001 trial, J Clin Oncol, 2014;32:1563-70.

44. Eisenberg BL, Harris J, Blanke CD, et al., Phase II trial of neoadjuvant/adjuvant imatinib mesylate (IM) for advanced primary and metastatic/recurrent operable gastrointestinal stromal tumor (GIST): early results of RTOG 0132/ACRIN 6665 I Surg Oncol, 2009:99:42-7.

45. Wang D, Zhang Q, Blanke CD, et al., Phase II trial of neoadjuvant/ adjuvant imatinib mesylate for advanced primary and metastatic/recurrent operable gastrointestinal stromal tumors: long-term follow-up results of Radiation Therapy Oncology
Group 0132, Ann Surg Oncol, 2012;19:1074-80.

46. McAuliffe JC, Hunt KK, Lazar AJ, et al., A randomized, phase II study of preoperative plus postoperative imatinib in GIST: evidence of rapid radiographic response and temporal induction of tumor cell apoptosis, Ann Surg Oncol, 2009;16:910-9.

47. Doyon C, Sideris L, Leblanc G, et al., Prolonged therapy with imatinib mesylate before surgery for advanced gastrointestinal stromal tumor results of a phase ii trial, Int I Surg Oncol, 2012;2012:761576.

48. Hohenberger $\mathrm{P}$, Langer $\mathrm{C}$, Wendtneret $\mathrm{CM}$, et al., Neoadjuvant treatment of locally advanced GIST: Results of APOLLON, a prospective, open label phase II study in KIT- or PDGFRA-positive tumors. ASCO meeting abstracts, Chicago, 2012 (Suppl.; Abstr 10031):30.

49. Blesius A, Cassier PA, Bertucci F, et al., Neoadjuvant imatinib in patients with locally advanced non metastatic GIST in the prospective BFR14 trial, BMC Cancer, 2011;11:72.

50. Rutkowski P, Gronchi A, Hohenberger P, et al., Neoadjuvant imatinib in locally advanced gastrointestinal stromal tumors (GIST): the EORTC STBSG experience, Ann Surg Oncol, 2013;20:2937-43

51. Gastrointestinal stromal tumors: ESMO Clinical Practice Guidelines for diagnosis, treatment and follow-up, Ann Oncol, 2012:23(Suppl. 7)'vii49-55

52. Therasse $P$, Arbuck SG, Eisenhauer EA, et al., New guidelines to evaluate the response to treatment in solid tumors. European Organization for Research and Treatment of Cancer, National Cancer Institute of the United States, National Cancer Institute of Canada, I Natl Cancer Inst, 2000;92:205-16.

53. Van den Abbeele AD, Gatsonis C, de Vries DJ, et al., ACRIN 6665/ RTOG 0132 phase II trial of neoadjuvant imatinib mesylate for operable malignant gastrointestinal stromal tumor: monitoring with 18F-FDG PET and correlation with genotype and GLUT4 expression, J Nucl Med, 2012;53:567-74.

54. Goh BK, Chow PK, Chuah KL, et al., Pathologic, radiologic and PET scan response of gastrointestinal stromal tumors after neoadjuvant treatment with imatinib mesylate, Eur J Surg Oncol, 2006;32:961-3.

55. Choi $\mathrm{H}$, Charnsangavej $\mathrm{C}$, Faria SC, et al., Correlation of computed tomography and positron emission tomography in patients with metastatic gastrointestinal stromal tumor treated at a single institution with imatinib mesylate: proposal of new computed tomography response criteria, J Clin Oncol, of new computed 2007 :1753-9.

56. Benjamin RS, Choi H, Macapinlac HA, et al., We should desist using RECIST, at least in GIST, J Clin Oncol, 2007;25:1760-4.

57. Tirumani $\mathrm{SH}$, Shinagare $\mathrm{AB}$, Jagannathan JP, et al., Radiologic assessment of earliest, best, and plateau response of gastrointestinal stromal tumors to neoadjuvant imatinib prior to successful surgical resection, Eur J Surg Oncol, 2014:40:420-8.

58. Bednarski BK, Araujo DM, Yi M, et al., Analysis of prognostic factors impacting oncologic outcomes after neoadjuvant tyrosine kinase inhibitor therapy for gastrointestinal stromal tumors, Ann Surg Oncol, 2014;21:2499-505.

59. Reichardt P, Blay JY, Gelderblom H, et al., Phase III study of nilotinib versus best supportive care with or without a TKI in patients with gastrointestinal stromal tumors resistant to or intolerant of imatinib and sunitinib, Ann Oncol, 2012:23:1680-7.

60. Blay JY, Kang YK, Rutkowski P, et al., Phase III trial of nilotinib versus imatinib as first-line targeted therapy of advanced gastrointestinal stromal tumors (GIST). ASCO; 2013; Chicago Clin Oncol; 2013; (suppl; abstr 10501^):31.

61. Trent IC, Wathen K, von Mehren M; Sarcoma Alliance for Research through Collaboration (SARC), A phase II study of dasatinib for patients with imatinib-resistant gastrointestina stromal tumor (GIST). ASCO; 2011; Chicago, J Clin Oncol, 2011:(suppl; abstr 10006):29

62. Montemurro M, Domont J, Blesius A, et al., Dasatinib first-line treatment in gastrointestinal stromal tumors: A multicenter phase II trial of the SAKK (SAKK 56/07). ASCO; 2012; Chicago, J Clin Oncol, 2012

63. Ganjoo KN, Villalobos VM, Kamaya A, et al., A multicenter phase II study of pazopanib in patients with advanced gastrointestinal stromal tumors (GIST) following failure of at least imatinib and sunitinib, Ann Oncol, 2014:25:236-40.

64. Benjamin RS, Schoffski P, Hartmann JT, et al., Efficacy and safety of motesanib, an oral inhibitor of VEGF, PDGF, and Kit receptors, in patients with imatinib-resistant gastrointestinal stromal tumors, Cancer Chemother Pharmacol, 2011;68:69-77.

65. Sawaki A, Yamada Y, Komatsu Y, et al., Phase II study of motesanib in Japanese patients with advanced gastrointestinal stromal tumors with prior exposure to imatinib mesylate, Cancer Chemother Pharmacol, 2010:65:961-7.

66. Kang YK, YoO C, Ryoo BY, et al., Phase II study of dovitinib in patients with metastatic and/or unresectable gastrointestinal stromal tumours after failure of imatinib and sunitinib, Br J Cancer, 2013;109:2309-15. 
Gastrointestinal Oncology

67. Wagner A, Yazji S, Morgan J, et al., A Phase 2 Study of the Klt Inhibitor XL820 in Patients with Advanced Gastrointestinal Stromal tumors (GIST) resistant to or intolerable to imatinib and/or sunitinib. AACR-NCI-EORTC International Conference Molecular Targets and Cancer Therapeutics Discovery, Biology and Clinical Applications; 2009; Geneva, Switzerland; 2009.

68. Joensuu H, De Braud F, Grignagni G, et al., Vatalanib for metastatic gastrointestinal stromal tumour (GIST) resistant to imatinib: final results of a phase II study, Br J Cancer, 2011;104:1686-90.

69. Montemurro M, Gelderblom H, Bitz U, et al., Sorafenib as third- or fourth-line treatment of advanced gastrointestinal stromal tumour and pretreatment including both imatinib and sunitinib, and nilotinib: A retrospective analysis, Eur $J$ Cancer, 2013;49:1027-31.

70. Park SH, Ryu MH, Ryoo BY, et al., Sorafenib in patients with metastatic gastrointestinal stromal tumors who failed two or more prior tyrosine kinase inhibitors: a phase II study of Korean gastrointestinal stromal tumors study group, Invest New Drugs, 2012;30:2377-83

71. Kindler $\mathrm{HL}$, Campbell N, Wroblewski $\mathrm{K}$, et al., Sorafenib (SOR) in patients (pts) with imatinib (IM) and sunitinib (SU)resistant (RES) gastrointestinal stromal tumors (GIST): Fina results of a University of Chicago Phase II Consortium trial. ASCO; 2011; Chicago, J Clin Oncol (Meet Abstr), 2011;(Suppl.; Abstr 10009):29.

72. Soria JC, Massard C, Magne N, et al.. Phase 1 dose-escalation study of oral tyrosine kinase inhibitor masitinib in advanced and/or metastatic solid cancers, Eur J Cancer, 2009;45:2333-41.
73. Le Cesne A, Blay JY, Bui BN, et al., Phase II study of oral masitinib mesilate in imatinib-naive patients with locally advanced or metastatic gastro-intestinal stromal tumour (GIST), Eur J Cancer. 2010;46:1344-51

74. Heinrich MC, Griffith D, McKinley A, et al., Crenolanib inhibits the drug-resistant PDGFRA D842V mutation associated with imatinib-resistant gastrointestinal stromal tumors, Clin Cancer Res, 2012;18:4375-84

75 Hoy SM, Ponatinib: a review of its use in adults with chronic myeloid leukaemia or Philadelphia chromosome-positive acute Iymphoblastic leukaemia, Drugs, 2014:74:793-806.

76. Michael C, Heinrich MV, Demetri GD, et al., A phase 2 study of ponatinib in patients (pts) with advanced gastrointestinal stromal tumors (GIST) after failure of tyrosine kinase inhibitor (TKI) therapy: Initial report. ASCO; 2014; Chicago, I Clin Oncol, 2014.

77. Demetri GD, Heinrich MC, Chmielowski B, An open-label phase II study of the Hsp90 inhibitor ganetespib (STA-9090) in patients (pts) with metastatic and/or unresectable GIST. ASCO; 2011; Chicago, I Clin Oncol; 2011.

78. Demetri GD, Le Cesne $A$, von Mehren $M$, et al., Final results from a phase III study of IPI-504 retaspimycin hydrochloride) versus placebo in patients (pts) with gastrointestinal stromal tumors (GIST) following failure of tyrosine kinase inhibitor (TKI) therapies, ASCO Gastrointestinal Cancers Symposium; 2010; 2010.

79. Conley AP, Araujo D, Ludwig J, et al., A randomized phase II study of perifosine (P) plus imatinib for patients with imatinib-resistant gastrointestinal stromal tumor (GIST). ASCO; 2009; Chicago,
J Clin Oncol; 2009

80. Schoffski P, Reichardt P, Blay JY, et al, A phase I-II study of everolimus (RAD001) in combination with imatinib in patients with imatinib-resistant gastrointestinal stromal tumors, Ann with imatinib-resistant

81. von Mehren M, George S, Heinrich MC, et al., Results of SARC 022, a phase II multicenter study of linsitinib in pediatric and adult wild-type (WT) gastrointestinal stromal tumors (GIST). ASCO; 2014; Chicago, J Clin Oncol; 2014.

82. Palbociclib Ups PFS in HER2-/ER+ Breast Cancer, Cancer Discov, 2014;4:624-5

83. Dickson MA, Tap WD, Keohan ML, et al., Phase II trial of the CDK inhibitor PD0332991 in patients with advanced CDK4-amplified well-differentiated or dedifferentiated liposarcoma, I Clin Oncol, 2013;31:2024-8

84. Montemurro M, Schoffski P, Reichardt P, et al., Nilotinib in the treatment of advanced gastrointestinal stromal tumours resistant to both imatinib and sunitinib, Eur J Cancer, 2009;45:2293-7.

85. Sawaki A, Nishida T, Doi T, et al., Phase 2 study of nilotinib as third-line therapy for patients with gastrointestinal stromal tumor, Cancer, 2011;117:4633-41.

86. Cauchi C, Somaiah N, Engstrom PF, et al., Evaluation of nilotinib in advanced GIST previously treated with imatinib and sunitinib, Cancer Chemother Pharmacol, 2012;69:977-82.

87. Piovesan E, Coco P, Palassini E, et al., Response to sirolimus in combination to tirosine kinase inhibitors (TKI) in three cases of PDGFRA-D842V metastatic gastrointestinal stromal tumor (GIST), ASCO; 2009; Chicago, J Clin Oncol; 2009. 